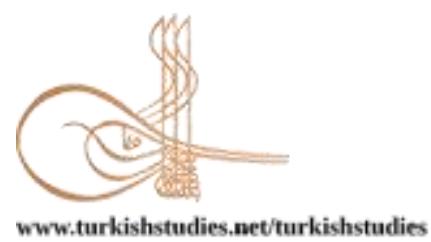

Turkish Studies

\title{
Kavramsal Sanatta Nesneden Arındırma ve Yeniden Bağlamsallaştırma Sürecinde Harita Kullanımı
}

\author{
The Use of Map in the Process of Dematerialization and Re-contextualization in Conceptual Art
}

\author{
Ümit Güvendi Ulutaş*
}

\begin{abstract}
It is known that the object of artworks has a special importance in the historical process. Works of art that have aesthetic value in terms of form and, beauty in other words, have managed to affect the audience emotionally throughout the historical process. After 1930's, it is seen that new thoughts related to the form and existence of the object of art start to emerge in art. Following a specific degree, these thoughts are seen to lead to a new movement called conceptual art. Within the conceptual art movement, it may be observed that many artists try to substitute thoughts instead of emotion in art by employing different objects, writing, performances, etc. In conceptual art, the main perspective is the de-objectification of art or to recontextualize objects that are presented to the audience as art objects by removing them from context. Throughout the historical process of art, it is seen that artists turn towards maps from time to time and produce maps. In the conceptual art movement, artists are seen to employ maps in their projects or as a solely intellectual tool in addition to the other examples. The aim of this study is to examine the artists who used maps in conceptual art in the 1960s and 1970s and the reasons and purposes of transforming these maps into intellectual tools. In this context, literature review was conducted in the study. Goal-oriented sampling method was applied in determining the artists. In the process of determining the artists, works with different characteristics from different dates are included. The result obtained from the whole study is that maps, which are complicated indicators, are used in conceptual art for similar purposes at the beginning and to express different purposes and different ideas later.
\end{abstract}

Structured Abstract: Deleuze establishes a relationship between art and the perceptible and conceptual world through employing the expression "While living in the conditions offered by the present time, the purpose of the artist is to transform the content of his life into a permanent universe" (cited by Bourriaud, 2005: 21). Upon the introduction of Conceptual Art in the history of art, it is seen that the duality of perceptual art and conceptual art emerged. The interest sensorily created by a work and the arts in which the object of the work has a special importance are defined as "Perceptual art", while conceptual art is generally expressed as art that prioritizes thought and comprehension rather than producing a perception of the eye and ear in particular.

Conceptual art heads towards the intellectual form rather than the sensory and perceptual one. At this point, the question "Can a non-sensory or non-perceptual art exist?" should be answered. It may be seen that the assessment of the physical object of a work of art and the object within the context of form started to lose its importance upon the applications of conceptual art and intellectual infrastructure. For that reason,

\footnotetext{
* Dr. Öğr. Üyesi, Nevşehir Hacı Bektaş Veli Üniversitesi, Güzel Sanatlar Fakültesi, Resim Bölümü Assistant Professor, Nevsehir Haci Bektas Veli University

ORCID 0000-0001-7317-8422

umutguvendiulutas@gmail.com

Cite as/ Atıf: Ulutaş, U. G. (2021). Kavramsal sanatta nesneden arındırma ve yeniden bağlamsallaştırma sürecinde harita kullanımı. Turkish Studies, 16(3), 1163-1179. https://dx.doi.org/10.7827/TurkishStudies.50110

Received/Geliş: 23 March/Mart 2021

Accepted/Kabul: 20 June/Haziran 2021

Checked by plagiarism software

Published/Yayın: 25 June/Haziran 2021

CC BY-NC 4.0
} 
conceptual art means a work in which the idea is the most important element, and the material is secondary, light, short-lived, inexpensive, unpretentious and or de-objectified ${ }^{1}$ (spiritualized or registered). Our conception of everyday art involves thinking the works of art as the kind of spatial-temporal objects found on walls or pedestals in museums and art galleries. An object is a tool or tools by which the artist conveys his ideas. The ontological challenge of conceptual art is related to the rejection of the role of this centrally important tool, the material one, in art.

After 1960, it was tried to go beyond aesthetic problems in Conceptual Art, which emerged as a new generation of artists. Mel Bocher who is one of the first generation of conceptual artists primarily associates the origins of the movement and an ideal conceptual understanding of art with the production of works in a linguistic context. There is a very heated debate within Conceptual Art about whether art requires an object. The tendency of not seeing the art object as matter de-objectification of art or spiritualizing it with another expression emerged during the period between late 1960's and mid-1970's. The issue of de-objectification of art is one of the topics at the center of conceptual discussions. Many art thinkers prefer to approach the subject more distantly even if de-objectification is perceived as a departure from a direct aesthetic effect, especially, formal beauty or aesthetic value.

It is seen that conceptual art practices in Latin America employ re-contextualization as a strategy in conceptual art instead of de-objectification. It may also be observed that the artists challenge the concept of aesthetics as well as the process of de-objectification thanks to the efforts of re-contextualization and they try to reposition art in the experience areas of life.

A map is regarded as a complex type of semiotic text with many possible reference frameworks such as political, medical, meteorological, demographic, military, etc. and many different purposes. Many conceptual artists, who have irreversiblely moved away from the art of painting, have forced the boundaries of expression, and are also interested in mapping and ready-made maps throughout this process. In 1959, Yves Klein, one of the pioneers of conceptual art, covered a school sphere with his trademark, blue pigment YKB. This work is an important example for the artists who will work with maps after him, and it has differentiated in terms of form from the first examples after him. Like other works which Klein produced, he is seen to apply modern aesthetic values to the sphere with the element of color in this conceptual work.

In the late 1960s, maps which were employed for artistic and intellectual purposes exhibit similar features in the projects carried out by Long, Kawara and Huebler. First of all, maps were used together in addition to the other objects in the projects and aimed at documenting a performance. In these works which are presented to the audience as the first conceptual works in art museums, it is seen that the concept of deobjectivation clearly prevails in the works presented to the audience and intellectual processes are emphasized by moving away from aesthetic value. It may be observed that ready-made maps are used in the projects and artists make small interventions to turn the maps into part of their subjective experiences.

In the 1970s, it is seen that conceptual artists began to break away from the first examples of conceptual art, especially in terms of formal sense. Thanks to their works shown above, the maps of Graves, Hiller, Boetti and Denes above are formally different from previous examples and can be interpreted to be closer to traditional aesthetic values. On the other hand, the project of Norman Daly called Llhuros included maps as a conceptual project. It is also stated that these maps adhere formally to traditional aesthetic values, but also carry the spirit of conceptual art.

During late 1960s, the most prominent examples of map use in conceptual art were given by the artists of the same period, 'Long, Kawara and Huebler'. In the works produced by these people, it may be seen that artists use the maps along with other objects within the framework of a project. In these projects which are usually performance-based conceptual works, maps are employed as a tool of reflecting the subjective ideas of artists about everyday life and documenting actions. On the other hand, maps, are complex indicator systems despite map reading is generally an ordinary and technical reading. Artists have used the maps they employed in their projects to document their subjective experiences, and afterwrds, interventions such as lines or writings applied by artists on those maps also serve to draw the viewer to other documents and processes in the project.

During 1970s, it is seen that other conceptual artists also continued to employ maps as a means of expression. After the first examples in the 1970's, it can be stated that some artists started to do different works especially formally and reflected modern or traditional aesthetic values, regardless of what the works 
produced in this sense and which are not exaggerated. Thus, it should be noted that the strategies of deobjecting or moving away from aesthetic values that begin with conceptual art are not implemented by some artists, but their intentions to bring their work to the forefront with their conceptual and intellectual characteristics also prevail in these artists.

Keywords: Conceptual Art, Map, the Object of Art, Artistic Form, Idea of Art

Öz: Tarihi süreçte sanat eserlerinin nesnesinin özel bir öneme sahip olduğu bilinmektedir. Biçimsel olarak estetik değere diğer ifadeyle güzelliğe sahip olan sanat eserleri tüm zamanlarda izleyenleri duygusal yönden etkilemeyi başarmıştır. 1930'lardan sonra ise sanatta, sanat nesnesinin biçimi ve varoluşuyla ilgili yeni düşüncelerin ortaya çıkmaya başladığı görülür. Bu düşüncelerin belli bir aşamadan sonra kavramsal sanat olarak tanımlanan yeni bir akıma yol açtığı görülmektedir. Kavramsal sanat akımı içerisinde pek çok sanatçının farklı farklı nesneleri, yazıyı, performanslar vb. kullanarak sanatta duygu yerine düşünceyi ikame etmeye çalıştıkları görülür. Kavramsal sanatta temel bakış açısı sanatın nesnesinden arındırılması veya sanat nesnesi olarak izleyicinin karşısına çıkarılan nesnelerin bağlamından kopartılarak yeniden bağlamlaştırılmasıdır. Sanatın tarihsel sürecinde sanatçıların zaman zaman haritalara yöneldikleri ve haritalar ürettikleri görülmektedir. Kavramsal sanat akımında ise sanatçıların diğer örneklerin dışında haritaları; projelerinde veya tek başlarına bir düşünsel araç olarak kullanmaya başladıkları görülür. Bu çalışmanın amacı kavramsal sanatta 1960 ve 1970'li yıllar kapsamında harita kullanan sanatçıları ve bu haritaların hangi amaçlarla nasıl düşünsel araçlara dönüştürüldüğünün incelenmesidir. Bu kapsamda çalışmada literatür taraması yapılmıştır. Sanatçıların belirlenmesinde amaca yönelik örneklem metodu uygulanmıştır. Sanatçıların belirlenmes sürecinde farklı tarihlerden farklı özellikler gösteren eserlere yer verilmiştir. Çalışmanın bütününde elde edilen sonuç karmaşık birer gösterge olan haritaların kavramsal sanatta başlangıçta benzer amaçlarla sonrasındaysa farklı amaç ve farklı düşünceleri ifade etmek için kullanıldığıdır.

Anahtar Kelimeler: Kavramsal Sanat, Harita, Sanat Nesnesi, Sanatsal Biçim, Sanat Fikri

\section{Giriş}

Deleuze "Şimdiki zamanın sunduğu koşulların içinde yaşarken sanatçının amacı, hayatının içeriğini kalıcı bir evrene dönüştürebilmektir" ifadesiyle sanatın algılanabilir ve kavramsal dünyayla ilişkisini kurmaktadır (akt. Bourriaud, 2005: 21). Sanat tarihinde Kavramsal Sanattan söz edilmeye başlanması ile birlikte algısal olan sanat ve kavramsal sanat ikiliğinin ortaya çıktığı görülmektedir. Bir eserin duyusal olarak yarattı̆̆ ilgi ve eserin nesnesinin özel bir öneme sahip olduğu sanatlar "Algısal sanat" olarak tanımlanırken, kavramsal sanat ise genelde duyuya özelde ise göze ve kulağa yönelik bir alg1 üretmekten ziyade düşünce ve kavrama öncelik veren sanat olarak ifade edilmektedir. Kavramsal sanat, düşünce ve kavramların sıradan bir şekilde ifade edilmesi ve çalışmaların geleneksel veya modern biçimsel özellikleri taşımaması yüzünden algısal sanat ile arasına önemli bir mesafe koymuştur (Cumming, 2018: 478-492). Bu ikililik sanatta kadim bir gelenekten kopuşu ve özel bir tepkiyi işaret eder. Kavramsal sanat bu bağlamda başlı başına yeni bir bakış açısı ve hâkim sanat felsefesine alternatif düşünüşlerin sonucu olarak var olmaya başlar.

Mantık ve felsefe gibi zihinsel süreçlerle yakından ilişkili olan Kavramsal Sanat genel bir tanımlamayla sanatı eserlerini kuramsal düzlemde çözümlemeyi ve üretmeyi amaçlamaktadır. Sanatın yapısını araştıran ve yeniden tanımlayan kavramsal sanat, bilimle özdeş görülerek herhangi bir sanat dalının çerçevesine girmeden bir tür tepki üretmiştir. Bu tepki genel olarak sanat nesnesinin metalaşması bağlamında değerlendirilmiştir. '1945 sonrası sanatı' sınıflandıran birçok yayın kavramsal sanatı çeşitli kategorilerde incelemiştir. Buna göre; "gösteri sanatı, oluşumlar, vücut sanatı, yeryüzü sanatı, çevresel sanat, süreç sanatı, fakir sanat ve video sanatı ile birlikte nesne sonrası sanat" kategorilerde üretilen çalışmalar ile kavramsal sanatın bir fenomen olarak belirdiği görülür. Tüm bu sanatların ortak özelliği olarak sanatçının iletmek istediği düşünce ve kavramlar odağa yerleştirilmiştir (Kolektif, 1997: 971). 
Sanat tarihi içinde pek çok dönemde farklı amaçlarla haritalar üreten sanatçılarla karşılaşılmaktadır. Kavramsal Sanatın ilk dönemlerinden başlayarak kavramsal işler üreten sanatçıların da haritalara farklı nedenlerle ve farklı hedeflerle yöneldikleri görülmektedir. Siradan ve gündelik nesneleri sanat nesnesine dönüştüren ve bu süreçte de sanat nesnesinin aurasını ortadan kaldırmaya çalışan kavramsal sanatçıların haritaları kullanış biçim ve amaçları bu çalışmada incelenmektedir. Çalışmanın temel amacı sanat nesnesinin dönüşümü bağlamında gündelik hayatın sıradan nesneleri ile anlatım olanakları arayan kavramsal sanatçıların harita gibi karmaşık göstergelerle ilişkisini sorgulamaktır. Bu sorgulamada biçimsel özellikler, sanatın nesneden arınması bağlamında yapılan biçimsel tercihler ve yeniden bağlamlaştırmalar incelenmiştir. Çalışma 1960-70 yılları ile sınırlandırılmıştır. Araştırmada haritalarla çalışan sanatçılar ile ilgili literatür taraması yapılmıştır. Kavramsal sanat bağlamında haritalarla çalışan ve çalışmada yer verilen sanatçılar ise amaca yönelik örneklem metodu ile belirlenmiştir. Amaca yönelik örneklem metodu ile çalışmanın amacı kapsamında örnek sanatçılar seçilerek konu ve ana tema, nicel değil nitel bir boyutta incelenmiştir. Çalışmada kavramsal sanatçılardan ilk örneklerin bazılarının birbirlerine benzediği fakat özellikle 1970 sonrası çalışmalarda farklı amaçlar, düşünsel süreçler ve esneyen bir biçim anlayışı ile kavramsal çalışmaların devam ettiği sonucuna ulaşılmıştır.

\section{Kavramsal Sanatın Sanat Tarihinde Varoluşu}

Donald Judd'un 1965'te ilan ettiği bildirisi, Minimalizmin temel amaçlarından birini özetlemiştir. Bu bildiri özünde "Sanat eserinin yalnızca ilginç olması gerekir" fikrini temele almaktaydı ve yoğun bir farkındalık yaratmayı ana amaç olarak belirlemişti. Bu farkındalığın belirli bir nesneye, malzemeye veya ortama veya hatta izleyicinin kendi vücuduna yönelik olup olmadığı, sanat eserine bağlıydı. Minimalistler 1960'larda projelerini tanımladıklarında diğer ilerici sanatçılar için formun estetik ilgisinin niyetleri ifade etmek için gerekli olup olmadığı sorusunu sormaya başladılar. Bu sürecin sonunda konuşulmaya başlanan "Kavramsalcılık" fikrin sanat eseri olduğunu savunmaktadır. Bir fikre yanıt olarak oluşturulan herhangi bir resim, heykel, çizim, baskı, fotoğraf veya bina, estetik ifadenin kendisinin aksine, sadece bir dokümantasyon parçasıdır, estetik ifadenin bir kaydıdır. Dada genel olarak Kavramsalcılık için bir kaynak olarak görülürken, fikir olarak sanat için en etkili modeli sağlayan kişi Marcel Duchamp olarak görüle gelmiştir (Arnason\& Mansfield, 2012: 558).

Genel kullanımı bir yana, 'Kavramsal Sanat' terimi 1961'de özellikle Fluxus sanatçısı Henry Flynt tarafindan ve Sol LeWitt tarafindan kullanılmıştı. Bununla birlikte, 1969'da Amerikalı Joseph Kosuth'un 'Art After Philosophy' adlı makalesinde kavram tabiri caizse tam olarak onaylandı ve bu noktada Kosuth, Duchamp'ı tarihsel bir dönüm noktası olarak tanımladı. Kosuth, bu çalışmasında kendinden önceki dönemlerdeki sanatın, fiziksel içeriği tarafından engellendiğini iddia etmiş̧i. Duchamp etkisini bir hazırlık aşaması olarak tanımlayan Kosuth, sonrasında ileri sanat arayışının ve sanatın ne olabileceğine dair analitik önermeler ortaya koymaya çalıştı. Bununla birlikte, Duchamp okuması dar bir şekilde sanatsal çalışmalara sanat statüsünün verilmesi konusuna odaklanmıştı. Tüm bu sürecin sonunda sanat nesnesinin ve biçimsel unsurların kabul edilen öneminin tahttan indirilmesi bir tür reformist ikonofobi doğurmuştur ve biçimin desteklediği duyusal ve duygusal zevkler yerine izleyicilere yaz1l beyanlar, belgesel bilgiler veya özetle fikirler ${ }^{1}$ sunulmaya başlanmıştır (Hopkins, 2000:177).

\footnotetext{
${ }^{1}$ Ortaya çıkan nesnenin biçiminden ziyade estetik fikrin önceliğe sahip olduğu düşüncesi pek çok kuramcı ve sanat tarihçisinin tanımlarıyla Rönesans'ta bile geçerliydi. Örneğin, Leonardo da Vinci'nin projeleri yarım bırakma alışkanlığı, biyografi yazarı Giorgio Vasari tarafindan, sanatçının formları maddi olarak gerçekleştirilemeyecek kadar mükemmel hayal edebilmesinin yani fikrin karşılığı olarak onu yaratacak bir forma sanatçının ulaşamamasının bir sonucu olarak açıklandı. Vasari'nin açıklaması, sanatçının sayısız tamamlanmamış eserini başarısızlıktan ziyade bir deha işareti olarak sınıflandırdı ve fikir ile sanat arasındaki bağlantının eski dönemlerdeki birlikteliği adına bir örnek olarak kullanıldı. Kavramsal sanatçılar ise Vasari'nin bu yorumlarını genellikle paylaşmadılar. Fakat Kavramsal sanatçılar Leonardo için üretilen bu yorumları paylaşmamış olsalar da fikirlerin nihayetinde gerçekleştirilmiş olsun ya da olmasın en özgün sanat biçimi olduğunu savunmuşlardır (Arnason\& Mansfield, 2012: 558).
} 
Kavramsal sanat duyusal ve algisal olandan ziyade fikirsel olana yönelmektedir. $\mathrm{Bu}$ noktada "Duyusal veya algisal olmayan bir sanat olabilir mi?" sorusu yanıt bulmalıdır. Lamarque (2007: 7-9), edebiyat ve şiir örneğine atıfta bulunarak, bu soruyu "evet" olarak yanıtlamaktadır. Bu fikir daha sonra algısal olanı vurgulayan ve dile ve betimlemeye önem veren bu tür kavramsal sanatın edebi sanatlarla özdeşleştirilebileceği düşüncesini teşvik eder. Ancak Lamarque bu meselenin daha dikkatli incelenmesini önermektedir. Çoğu kavramsal sanat kendini kararlı bir şekilde duyusal olanın güzelliğine ve cazibesine diğer ifade ile estetiğe karşı koymaktadır. Bu bağlamda sanatın hoş, bakması kolay, güzel, düzenli ve birleşik olması gerektiği fikrine isyan ettikleri açıktır. Kavramsalcılar bu sebeple çoğunlukla çirkin, iğrenç, geçici, şok edici, ucuz malzemeler, kitsch, bayağı, sıkıcı, sıradan olan nesneleri ararlar. Pek çok eleştirmen ve izleyici için, kavramsal sanatın sanat referanslarını bu kadar şüpheli kılan, kesinlikle estetiğe karşı bu bilinçli dönüştür. Buna karşılık kavramsal sanatçılar, estetikten uzaklıklarını pekiştirmek için fikirlerin algisal olana üstünlüğünü vurgularlar.

Kavramsal sanat uygulamaları ve düşünsel alt yapısı ile birlikte sanat yapıtının, fiziksel nesnesinin ve nesnenin biçimsel bağlamda değerlendirmesinin öneminin azaldığı görülmektedir. Kavramsal sanat bu sebeple fikrin en önemli öge olduğu ve malzemenin ikincil, hafif, kısa ömürlü, ucuz, iddiasız ve veya nesneden arındırılmış ${ }^{2}$ (manevileştirilmiş veya kaydileştirilmiş) olduğu iş anlamına geliyor. Gündelik sanat anlayışımız, sanat eserlerini, müzelerdeki ve sanat galerilerindeki duvarlarda veya kaidelerde bulunan türden mekansal-zamansal nesneler olarak düşünmeyi içerir. Nesne, sanatçının fikirlerini ilettiği bir araç veya araçlardır. Kavramsal sanatın ontolojik meydan okuması, merkezi öneme sahip olan bu aracın yani maddi olanın sanattaki rolünün reddedilmesi ile bağlantılıdır. Kavramsal sanatçı Joseph Kosuth'un "Sanat fikri ve sanat aynıdır" yorumunda bu reddedişin zemini hazırlanmaktadır. Bu reddediş üç şekilde ortaya çıkar. Birincisi, her sanat biçimine "uygun" olan belirli bir ortam olduğu yönündeki modernist fikrin reddi söz konusudur; örneğin kavramsal sanat eserleri bazen geniş bir medya yelpazesini (bazen karma medya çalışmaları olarak da bilinir) içerir. İkinci olarak, fiziksel şeyin takdir için uygun nesne olduğu fikrinin reddi ortaya konulmaktadır. Örneğin kavramsal sanat eserleri bazen sadece daktilo edilmiş kelimelerden veya bu amaca uygun görünmeyen çok zayıf fotoğraflardan oluşmaktadır. Üçüncüsü, Lippard'ın (1973) sanatın nesnesinden arındırılması dediği şey vardır; örneğin, Robert Barry'nin sadece şu sözlerden oluşan bir eseri var: "All the things I know but of which I am not at the moment thinking - 1:36 pm, June 15, 1969"3 (Davies vd, 2009: 177).

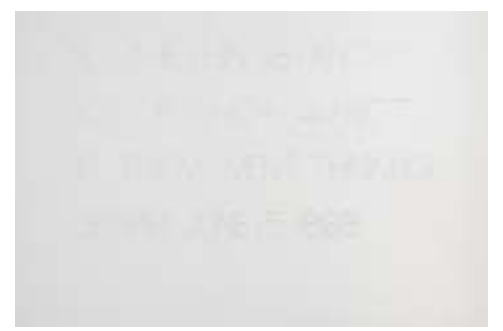

Görsel 1: Robert Barry'nin duvar üzerine kalemle yazılmış "All the things I know but of which I am not at the moment thinking - 1:36 pm, June 15, 1969" sözlerini içeren kavram çalışması (Brooklyn Rail, 2020).

1960 sonrasında yeni bir sanatçı kuşağı olarak beliren Kavramsal Sanatta estetik sorunların ötesine geçilmeye çalışılmıştır. İlk kuşak kavramsal sanatçılardan Mel Bocher akımın çıkış noktalarını ve ideal bir kavramsal sanat anlayışını öncelikle çalışmaların dilsel bağlamda

\footnotetext{
${ }^{2}$ Kaydileştirme veya manevileştirme kavramı orijinal İngilizce metinlerde 'Dematerialization' olarak kullanılmıştır. Dematerialization kavramı Kavramsal sanatta sanat nesnesi olarak kullanılan maddenin artık maddi olmadığını fikirini anlatmaktadır. Diğer bir ifade ile sanatın nesneden arınması anlamına gelmektedir.

3 "Bildiğim ama şu anda düşünmediğim her şey- 15 Haziran 1969 13:36" anlamına gelmektedir.
} 
üretilmesiyle ilişkilendirmektedir. Dilsel karşıllğı olan kavramsal işlerin bir bakıma izleyici tarafindan tanımlanabilen ve dil vasıtasıyla deneyimlenebilen bir yapıda olması gerektiğini vurgulayan Bocher biriciklik ve sanatsal aura gibi biçimle alakalı hususlara da karşı çıkmıştır (Antmen, 2008: 195). Çağdaş sanat pratikleri için bir referans noktası olarak kabul gören kavramsal sanat özellikle dil kullanımıyla ve yazının eserlerde bu amaç ekseninde varoluşuyla tanımlanmaktadır. Bu sebeple Kavramsal Sanatın yazıyı sanatsal bir uygulama olarak yeniden tanımladığı görüşü hakimdir. Kavramsal sanatçılar dili; özdeşlikler, ifadeler, talimatlar, komutlar, gözlemler, açıklamalar, önermeler, alıntılar, tartışmalar vb çeşitli şekillerde kullanmışlardır. Çalışmalar genellikle fotoğraflar, nesneler, eylemler veya haritalarla birleştirilmiş ve başlıklar, kartpostallar, eskizler veya denemeler olarak sunulmuştur (Kalyva, 2017: 1). Tüm bu denemelerde sınırsız düzeyde ortam arayışına giren sanatçıların yazıyı ve alışıla gelmedik nesneleri kullanmaları sanat nesnesi ve bu nesnenin estetik değeri sorunsalını ortaya çıkarmıştır.

\section{Sanatın Nesneden Arınması}

Sanatın bir nesneyi gerektirip gerektirmediğine dair Kavramsal Sanat içinde oldukça hararetli bir tartışma söz konusudur. Sanat nesnesini madde olarak görmeme, sanatı nesneden arındırma veya diğer bir ifade ile manevileştirme eğilimi 1960'ların sonlarından 1970'lerin ortalarına kadar geçen süre zarfında ortaya çıkmıştır. Greenberg sanat içinde ortaya çıkan bu eğilim aydınlatmaya çalışmıştır. Greenberg ${ }^{4}$, avangardın tarihi ile ilişkilendirerek, sanatların her birinin kendi özünü ifade etmeye çalıştı̆̆ını ve bunun gelişen bir özeleştiri süreci olduğunu ifade etmiştir. Yazar ayrıca her bir sanatın uygulamasından kimi özelliklerin kademeli olarak ortadan kaldırılması biçimini aldığını ve Kavramsal sanatta bu durumun sanat eserinin nesnesine kadar ulaşmış olduğunu vurgular (Matravers, 2007).

Amerikalı Kübist olan Joseph Schillinger "The Matematical Basis of the Arts" isimli kitabında sanatın tarihsel gelişimini ele almış ve bir süreç olarak sanatı birbirinin yerine geçen beş kısımda incelemiştir:

1. Biyolojik bir taklit aşaması olan preestetik;

2. Geleneksel-estetik, sihir, ritüel-dini sanat;

3. Duygusal-estetik, duyguların sanatsal ifadeleri, kendini ifade etme, sanat uğruna sanat;

4. Ampirisizm, deneysel sanat, roman sanatı ile karakterize rasyonel estetik;

5. Kusursuz bir sanat ürününün üretimini, dağıtımını ve tüketimini mümkün kılacak ve sanat formlarının bir füzyonu ve son olarak "sanatın parçalanması" ile karakterize edilecek olan bilimsel, post-estetik, diğer ifadeyle fikrin soyutlanması ve özgürleşmesi (akt, Lippard \& Chandler, 1968).

Lippard ve Chandler artık son iki aşama arasında bir geçiş döneminde olabileceğimizi ifade etmektedirler. Son iki aşamadan birisi yukarıda da ifade edildiği üzere sanat nesnesinin madde olmaktan çıkışını anlatmaktadır. Ancak yazarlara göre bunları görsel sanatların geçeceği son aşamalar olarak tam anlamıyla kavramak da oldukça sorunludur. Manevileştirilmiş ve maddeden bağımsız hale getirilen sanat, görsel olmayan vurguları nedeniyle yazarlar tarafından post-estetiktir olarak tanımlanmaktadır. Lippard \& Chandler'ın ifadesiyle sanat eserleri; sözcükler gibi, fikirleri aktaran işaretlere dönüştüğünde, bunlar kendi başlarına şeyler değil, nesnelerin sembolleri veya

\footnotetext{
${ }^{4}$ Kavramsal sanat özetle ikinci Dünya Savaşı sonrasında ortaya çıkan soyut dışavurumculuk ve boyasal resim sonrası soyutlama akımlarının kuramcısı olan Greenberg'e ve onun modern biçimcilik kuramlarına temelden karşı çıkmaktadır. Greenberg'ün çerçevesini çizdiği 1945 sonrası biçimci sanat ve vurgusunu yaptığı estetizm Kavramsal Sanatta ret edilen ana unsurdur. Böylelikle biçimi ve estetiği reddeden kavramsal sanatçılar Greenberg'ün malzemeyi göstergeyi ve boyayı öne çıkaran kuramsal kavrayışını yeni bir bakış açısı ve felsefi alt yapı ile değiştirmeyi hedeflerler (Kolektif, 1997.971). Bu noktada kavramsal sanatın tanıklarından ve süreçteki önemli kuramcılardan olan Greenberg ve kavramsal sanatçılar arasında bir gerilimin olduğu ifade edilmelidir.
} 
temsilcileridir. Böyle bir çalışma, kendi başına bir amaç veya "sanat olarak sanat" olmaktan çok, bir ortamdir (1968).

Lucy Lippard ve John Chandler 1968 yılında yayınlanan ve Kavramsal Sanat adına ufuk açıcı bir çalışma olduğu vurgulanan "The Dematerialization Of Art" isimli makalelerinde sanatsal üretimdeki sonlu nesneleri üretmekten söz ettiler ve genel olarak nesne yapımından uzaklaşma eğilimini tespit ettiler. Özünde bu eğilim galeri ziyaretçilerinin özel beklentilerine meydan okuma potansiyelini barındırmakta ve bunun yerine onları katılımcı olarak meşgul etmeyi amaçlamaktadır. Sanata verilen geleneksel tepkilere, tipik olarak onunla ilişkilendirilen materyallere ve eleştirmenin, çalıșmanın biçimsel veya duygusal etkisini değerlendirmedeki rolüne meydan okumak kavramsal sanatın diğer boyutu olarak sanatın nesnesinden arınması sürecini desteklemiştir (Kalyva, 2017: 1).

Kavramsal sanatta nesneden kopuşla birlikte 'sanat yapıtı oluş' ile ilgili tartışma başlamıştır. $\mathrm{Bu}$ tartışmada genel eğilim "kavramsal sanatta yapıt sanatçının iletmek istediği düşünce ve kavramdır" şeklindedir. Bu anlamda düşünce ve kavramın merkeze alınarak nesneden arındırılan bir sanatsal süreçte sanat üretimi, izleyiciyi daha etken bir hale getirmeyi amaçlamıştır. $\mathrm{Bu}$ amaç ekseninde sanat yapıtının bir meta veya fetiş olarak varoluşunu kavramsal sanatçılar sekteye uğratmaya uğraşır. Böylelikle sanatın bu yeni bakış açısından düşünsel bir süreç olduğu ve düşünceyi veya kavramı iletmek için fetişleşmiş bir nesneye gereksinim olmadığı vurgusu yapılır (Kolektif. 1997: 971). Kavramsal sanat tüm bunların 1şı̆̆ında geleneksel ve modern kavrayışın ötesinde sanat nesnesinden vazgeçiş ve kalıplaşmış estetik değer (güzellik) teorilerinden uzaklaşmayı tartışmaya açmıştır.

Sanatın nesneden arındırılması konusu kavramsal tartışmalarının odağındaki konulardan birisidir. Nesneden arınma doğrudan estetik bir etkiden özelliklede biçimsel güzellik veya estetik değerden uzaklaşma gibi algılansa bile pek çok sanat düşünürü konuya daha mesafeli yaklaşmayı tercih eder. Schellekens (2007:90), kavramsal sanat ve sonrasında karşılaşılan eserlerde sanatın bilişsel değerine ve sanatın nesnesinden ayrılmasına yönelik ikili bağlılığının, gerçekte estetik değerin reddini gerektirmediğini ifade eder. Kavramsal sanatta estetik değere, söz konusu estetik nitelikler, bu fikrin temsil edildiği araç ortamından ziyade kavramsal sanat yapıtının kalbindeki fikre atfedildiği sürece izin verilebilir düşüncesinde olan yazar, geleneksel değer modelinin bile hala geçerli olabileceğini savunur. Schellekens'e göre kavramsal sanat eserleri hem bilişsel hem de estetik değere sahip olabilir. Bir şekilde diğerini zayıflatmak veya diğerini olumsuz etkilemek yerine, bu iki tür değer, kavramsal sanata ilişkin değerlendirmemizde fiilen etkileşime girebilir ve birbirlerinden fayda sağlayabilir. Yazarın kavramsal sanatta nesneden arınma ile ilgili en önemli vurgusu ise kavramsal sanat eserlerinin daha geleneksel olanlardan çok farklı olmaması ile ilgilidir. Yazar için sanat yapııının başarısı, en azından bir dereceye kadar, sanatçının fikri temsil etmek için uygun ortamı seçip seçmediğine bağlıdır. Kavramsal Sanatın nesneden arınması ile estetikten kopuş düşüncesine bir itirazda Bourriaud'tan gelmektedir. Bourriaud'a (2005: 122) göre "Kavramsal sanatın estetiği zaten saptamaya dayalı, olgusal, kanıtlayıcı bir estetiktir". Bourriaud bu durumun özellikle video ve kavramsal sanat arasındaki ilişki ile belirginleştiğini bildirir.

Kavramsal Sanat ideolojik ve toplumsal içerikli yapılara sanatta yer verilmesine de karşı çıkmaktadır. Modern sanatta Dışavurumculuk akımının bu süreçte eleştirildiği görülür. Kavramsal sanat duyguyu yadsıyan akılcı bir çerçeve belirleyerek düşüncenin önemini göstermeyi hedefler. Bu bağlamda kavramsal sanatçılar için en önemli unsur üretilecek gerçekliktir ve gerçeklik arayışı kapsamında düşünsel sistemler geliştirmeye çalışırlar ve estetize edilen temsillerden sanatlarını arındırma uğraşı içine girerler (Kolektif, 1997: 971). Bu açıdan kavramsal sanatta ve sonrasında sanatçıların farklı ortam arayışlarına girdikleri görülmektedir. Bu arayışlar içinde nesneden kopuş belirgin bir özellik gibi görünse bile nesnenin estetik özelliklerinden vazgeçme konusu özünde sanat nesne ve izleyici arasındaki duygu ilişkisi ile ilgilidir. Bu ilişkinin sorunlu olduğu düşüncesi oldukça eski bir fikre dayanır. Platon'nun sanatla ilgili düşünceleri incelendiğinde sanat ve duygu ilişkisinin düşünceyi olumsuz etkilemesinden söz ettiği görülür. Bu bağlamda kavramsal sanatın 
önceliği düşünceyi duygudan olabildiğince arındırmak ve düşünce üretmek olduğu düşünüldügünnde Platonist bir fikri süreçle karşılaşıldığı ifade edilmelidir. Örneğin süreç içinde sanatçıların dilsel göstergelere yani yazıya veya bu çalı̧̧mada da gösterilen daha komplex göstergeler olan haritalara yöneldikleri görülmektedir.

Antmen'e göre Kavramsal Sanat güçlü bir etki yaratmasına rağmen sanatı nesnesinden arındırma bağlamında teorikte ortaya atılanın ötesinde pratikte başarısızlığa uğramıştır. Antmen bu yorumu nesnesizleşme konusunun temelini oluşturan sanatın metalaşma süreci ile ilişkilendirmektedir ve Kavramsal Sanatın da bu ticarileşmenin bir parçasına dönüştügünü ifade eder (Antmen, 2008: 196).

Öte yandan Latin Amerika'daki kavramsal sanat uygulamalarının, nesneden arındırma yerine yeniden bağlamsallaştırmayı kavramsal sanatta bir strateji olarak kullandıkları görülmektedir. Yeniden bağlamsallaştırma çabaları ile sanatçıların nesneden arındırma süreçleri gibi estetik kavramına meydan okuduğu ve sanatı hayatın deneyim alanlarına yeniden yerleştirmeye çalıştıkları görülmektedir. Bu gurup kavramsal sanatçılarında dil kullandıkları fakat diğer guruptan farklılaştıkları görülmektedir. Yeniden bağlamsalaştırma süreçlerine emek harcayan sanatçıların nesneleri ve anlamı uygun hale getirdikleri, onları yeniden bağlamsallaştırdıkları, yan yana koyarak göndermeleri ve değeri yeniden semiyotize ettikleri ifade edilir. Kişinin gördüğü ve okuduğu işler; sanat ve siyaset, etik sorumluluk, kültürel hafiza ve ulusal kimlik arasındaki ilişki hakkında sorular üretir. Yeniden bağlamsalaştırma üzerine kavramsal işler üreten sanatçıların parçalanmış bir kamusal alanı siyasi açıdan güçlü bir site olarak yeniden bir araya getirmek ve farklı düşünme ile farklı hareket etme olanaklarını yaratmaya çalıştıkları görülmektedir (Kalyva, 2017: 82-94).

Aşağıda Görsel 2. de sunulan eser üzerine düşünülürse, bu eserde Kosuth'un nesneden arındırma stratejisini özellikle yazı ile gerçekleştirirken sandalye fotoğrafı ve sandalyenin kendisi ile nesneleri yeniden farklı bir bağlama sokmaya çalıştı̆̆ı görülmektedir. Biçimsel güzellik önemsenmediği gibi yüksek beceriden ziyade fikri yansıtan sıradan bir tasarım ortaya çıkmıştır. Bu sebeple hem nesneden arındırma yani estetik değerleri hiçe sayma hem de yeniden bağlamsallaştırma yöntemlerinin de birlikte kullanılabildiği ifade edilmelidir.

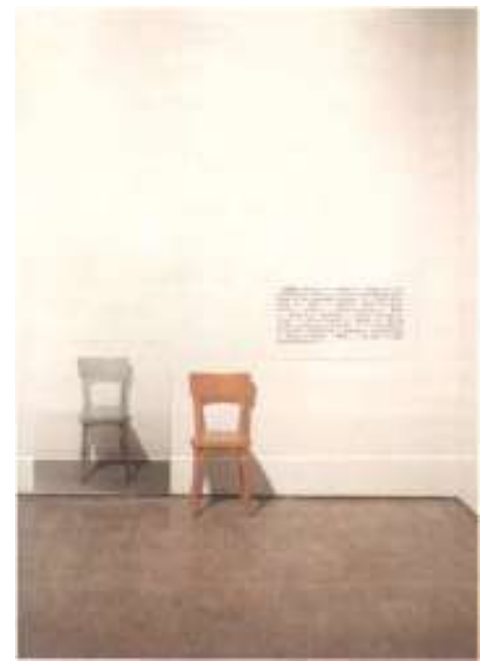

Görsel 2: Joseph Kosuth, “Bir ve Üç Sandalye”, 1965 (Moma, 2021).

Fleming ve Honour'a (2016: 854) göre bu ve benzeri kavramsal işlerde sanatçının el becerilerine bağlı ortaya çıkacak olan biçimsel güzellik geri plana atılmaktadır. Bu nedenle kavramsal çalışmalarda sanatçının fikirleri ile fiziki gerçeklikle arasındaki özel ilişkinin karakteri sorgulanmaktadır. Kavramsal sanatın öncülerinden Sol LeWitt Kavramsal Sanatın nesneden 
arındırılan biçiminin nesneleşmeden önce tasarlanan fikirle bağlantılı olduğunu ve bu fikrin fiziki uygulamasının ise formalite olduğunu ifade etmektedir.

\section{Kavramsal Sanatta Harita Kullanımının İlk Örnekleri}

Bir harita, politik, tıbbi, meteorolojik, demografik, askeri vb birçok olası referans çerçevesine ve birçok farklı amaca sahip karmaşık bir semiyotik metin türü olarak görülmektedir. Aslında, haritaların, çok çeşitli konuları ve kullanımları kapsayan ve de çok çeşitli amaçlar için gerekli olarak görülmesi, karmaşık göstergebilimsel özellikler geliştirmiş olmaları ile ilgilidir. Bir haritayı okumak ve neden öyle göründügünü anlamak, onun altında yatan amacı da anlamaktır (Wollen, 30). Birçok sanatçının sanatsal üretimlerine haritaları dahil ettiği gerçeğini belgelemek adına 2006 yılında yapılan bir katalog çalışmasında sadece kavramsal sanatçıların değil pek çok başka bağlamdaki sanatçının da haritalara yöneldiği gösterilmiştir. Bu katalog çalışması 20. yüzyılı kapsayan 218 sanatçıyı listelemektedir (Wood, 2006). Kavramsal sanatçıların pek çok sıradan nesneye çalışmalarında yer verdikleri gibi aslında sanatsal olmayan ama kapsamlı ve karmaşık gösterge olarak yorumlanabilecek haritaları da sanatsal fikirleri ifade etmekte kullandıkları görülmektedir. Özellikle ilk örneklerde farklı amaçlar ve uygulamalarla karşılaşıldığı görülür.

Resim sanatından geri dönüşü olmayan bir şekilde uzaklaşan pek çok kavramsal sanatçı, ifade sınırların zorlamış, bu süreçte haritalamaya ve hazır haritalara da ilgi duymuştur. Kavramsal sanatçılar dokümantasyona olan ilgileri sayesinde haritanın bir mekânsal temsil modu olarak değerini fark etmişlerdi. 1959'da kavramsal sanatın öncü isimlerinden olan Yves Klein, ticari markası olan mavi pigmenti YKB ile bir okul küresini kapladı. Bu çalışma uzay çağında popüler küresel haritalamaya hâkim olacak mavi gezegen temasını öngörüyordu (Cosgrove, 2005: 41). Bu çalışma kendisinden sonra haritalarla çalışacak sanatçılara önemli bir örnek teşkil ederken bir taraftan da biçimsel olarak kendisinden sonraki ilk örneklerden farklılaşmıştır. Klein'ın, ürettiği diğer işler gibi bu kavramsal çalışmasında renk unsuru ile modern estetik değerleri küreye uyguladığı görülür. Bu bağlamda bir öncü örnek olarak ortaya çıkan bu iş özellikle aşağıda verilen ilk örneklerden biçimsel olarak ayrılmaktadır. Sanatçının küreyi yeniden bağlamsallaştırdığı ve bu nesneyi bir düşünsel araca çevirirken estetik değerden de vazgeçmediği ifade edilebilir.

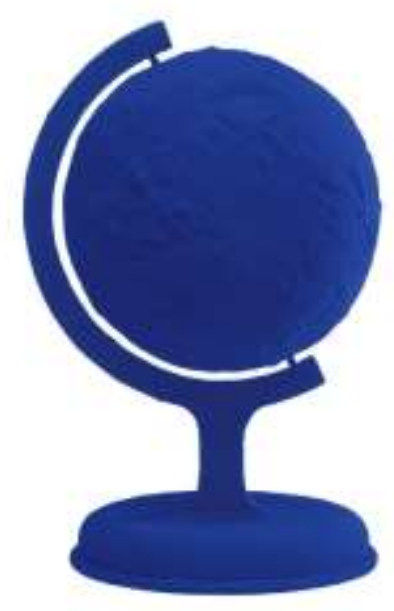

Görsel 3: Yves Klein, Mavi renge boyadığı dünya (Yves Klein, 2021)

Richard Long, 1967'den başlayarak 'yürüyüşten' heykel yapma niyetiyle haritaları kullanan ilk sanatçılardan birisi olarak karşımıza çıkmaktadır. Sanatçı önce fotoğraflarla yürüyüşleri belgelemeye başlamıştır, ancak kısa süre sonra bu fotoğraflara harita ve metin eklemiştir. Sanatçının belgeler veya anıtlar yaratabileceğini söyleyen fakat aslında tüm bunların sadece ayak izleri olduğunu vurgulayan Long, ilk harita parçasını "Ben Nevins Hitch-Hike" ismiyle bilinen 
işinde kullanmıştır. Bir tür performans olarak üretilen bu çalışmada sanatçı Londra'dan Ben Nevis'in zirvesine gidip gelirken otostopla ve yürüyerek bir yolculuğa çıkmıştır. Süreç içinde altı gün boyunca her gün saat 11: 00' da biri yukarı, diğeri aşağı doğru olmak üzere iki fotoğraf çekmiştir. Çalışma, yolculuktan, üzerinde rotasının işaretlendiği bir haritadan ve fotoğraflardan üretilmiştir (Wood, 2010: 204).

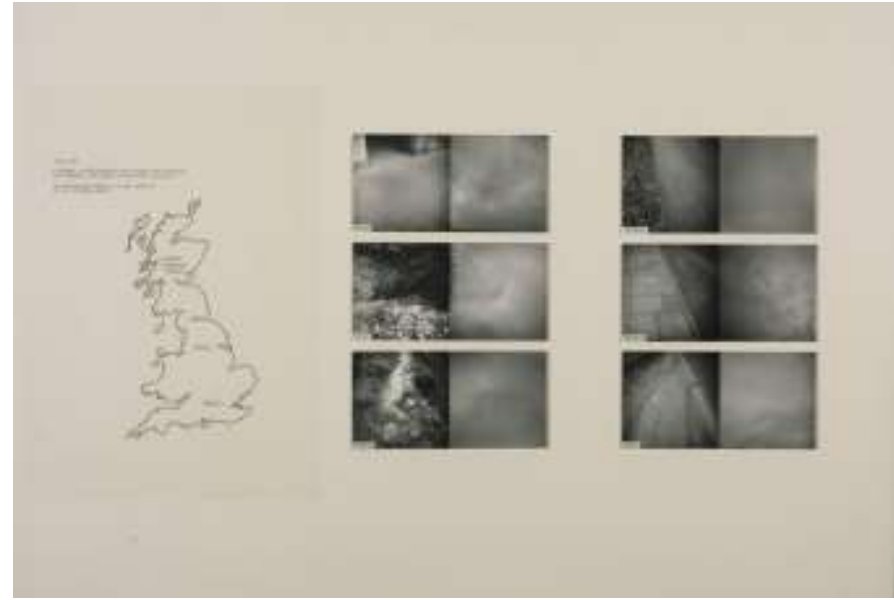

Görsel 4: Richard Long "Ben Nevins Hitch-Hike" tanınan, fakat literatürde "United 1968" şeklinde geçen çalışması (Tate Museum, 2020).

Kavramsal sanat haritaları, hareketin en başında ortaya çıkmaya başlamıştır. 1968 yılında hem Mexico City'de On Kawara'nın "I $I$ Went" serisinin lansmanının gerçekleştirildiği hem de Douglas Huebler'in 'Site Sculpture Projects' isimli serisi kapsamında '42nd Parallel Piece' ve 'Windham College Pentagon' isimli yapıtlarında da haritaların kullanıldığı görülmektedir. Kawara bu çalışmasında, kırmızı bir tükenmez kalem kullanarak şehir haritasında izlenen bir güzergahı işaretlemiştir. "İ Went" isimli harita çalışması On Kawara tarafından üretilen diğer benzer seriler gibi, bir öz belgeleme biçimi olarak tanımlanmıştır. Belgelenen davranış sanatçının şehir içindeki yörüngesini izliyordu. Gerçekte, Kawara'nın bu çalışması, sözlü metnin yanı sıra semiyotik haritalama sistemini kullanan bir tür ayrıntılı kişisel günlüğün bir parçasını oluşturur. Bu haritaların teması, bir şehir deneyiminden ziyade, On Kawara'nın kendi hayatının deneyimidir ve belirli bir şehir içinde dolaşmayı içerir (Wollen, 1999: 30).

Kawara, 'I Met' ve 'I Got Up' dizisini başlattıktan kısa bir süre sonra Mexico City de 'i Went' isimli bu harita çalışmasına başlamıştır. Her gün hareketlerini fotokopi haritalarda, tutarlı boyutlara büyütmek veya küçültmek suretiyle işaretlemiştir. Sanatçı konumlarını ve en sevdiği uğrak yerleri içeren alanları kırparak çizelgesini oluşturmuş ve Sonunda ayrı ayrı plastik kılıflara yerleştirerek bir seri çıkarmıştır (Guggenheim Museum, 2021). 


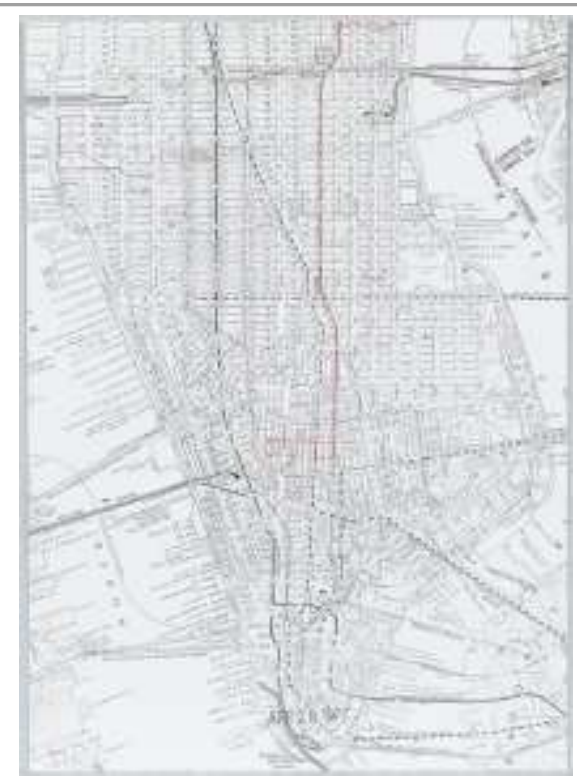

Görsel 5: On Kawara'nın “I Went” isimli çalışmasından bir örnek (Guggenheim Museum, 2021).

Haritaları dokümantasyon olarak kullanan Huebler "Harita sadece bir haritadır, biliyorsunuz. Bu gerçek bir şey değil ve yine de bunun gerçek bir şey olduğunu varsaymaya başladık " demiştir. Huebler'in atıfta bulunduğu "gerçek şey" muhtemelen ürettiği geçici sanat olayıdır. Sanat dünyasında bu ve benzeri kavramsal işlere karşı çıkan pek çok isim olmuştur. Ancak Huebler'in çok iyi farkında olduğu ve israr ettiği şey; "eğer geçici sanat olayı belgelenirse, o zaman hiçbir şey belgelerin metonimik olarak sanat nesnesi yerine geçmesini engelleyemez" (Alberro, 2001: 9).

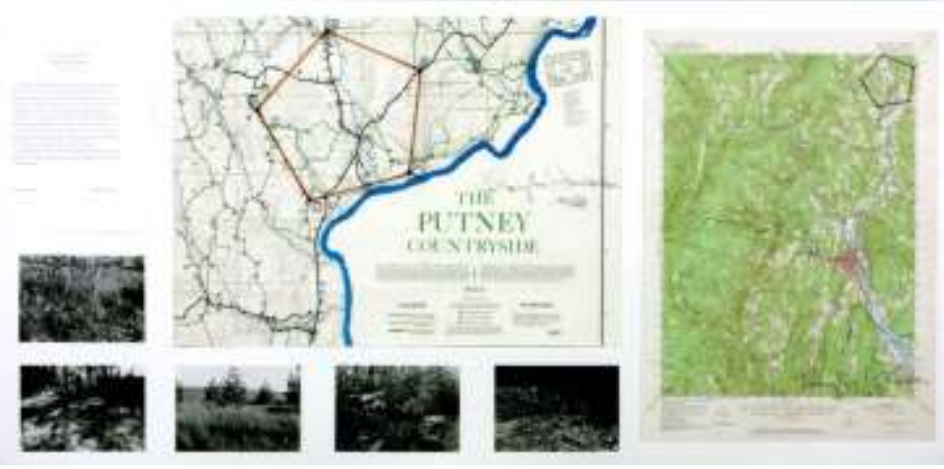

Görsel 6: Douglas Huebler, Site Sculpture Project, Windham College Pentagon (Tate Museum, 2020).

New Yorklu sanatçı Douglas Huebler'in 'Site Sculpture Projects' isimli serisinde haritalar, alanları örneklemek ve heykel kavramını yeniden tanımlamak amacında olan projeleri belgelemek üzere ikili bir rol oynamıştır. 42nd Parallel, isimli çalışmasında Amerika Birleşik Devletleri'nin her biri tam olarak 42 derece Kuzey enlem çizgisinde uzanan on dört kasabası tanımlanmıştır. Huebler'in diğer çalışmaları da ağırlıklı olarak haritaları barındırmıştır. 'Location Piece \#2' için, farklı sayıdaki su bidonları Kaliforniya çölündeki işaretli noktalara gömülmüştür. Bu işlem sonrasında çeşitli harita türlerinde gömülen bidonlar belgelenmiştir. Sanatçı, bu çalışmasında Shell firmasının otomobil haritalarını, havayolu güzergâh haritalarını ve kentsel yol haritalarını kullanarak, modern kültürdeki küçük haritaların her yerde bulunup kullanılamayacağına değinmiştir (Cosgrove, 2005: 41). 
Huebler'in haritalarla ürettiği kavramsal ilk çalışmalarında, toplu üretilmiş olan sıradan topografik yol haritalarını kullandığı görülür. Bir keçeli kalem yardımıyla, daha sonra yapılacak yolculuklarını yol haritalarında bir dizi kısa araba gidiş-dönüş yolculuğunu şeklinde planlamıştır. Haritalar, tüm yolculukları bir varlık yani zaman ve uzaydaki hareketin bir açıklaması olarak "kaydetme işlevi görmüştür. Keçeli kalemle rastgele bir şekilde çizilen rotalar hakkında önceden bilgi sahibi olan sanatçı böylelikle gezileri, otoriter kontrolü ret eden, tanımlanmamış operasyonlar olarak gerçekleştirdi. Huebler, haritaların üzerinde yer alan basit bilimsel dili kullanarak haritaları kuru metinsel açıklamalarla tamamladı. Sanatçının haritalarla birlikte sunduğu tamamlayıcı metinler şiirsel veya felsefi oluştan tamamen arındırılmıştır. Bu yazıların tek işlevleri parçaların parametrelerini tanımlamaktır. Bu açıdan Huebler'in kartografik çalışmaları, sanatsal öznelliğe erişim sağlamayan, tamamen kendi kendine düşünen anlatıları ifade etmeyi hedeflemiştir (Alberro, 2003: 83).

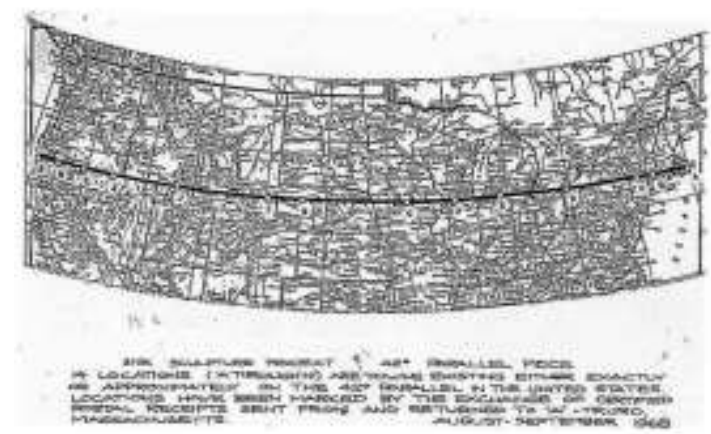

Görsel 7: Douglas Huebler, 'Site Sculpture Project' isimli seriden '42nd Parallel' isimli eser (Art Wiki French, 2020)

1960'ların sonlarında Long, Kawara ve Huebler isimli sanatçıların gerçekleştirdikleri projelerde sanatsal ve düşünsel amaçlarla kullanılan haritalar benzer özellikler sergilemektedir. Öncelikle haritalar projelerde başka nesnelerle bir arada kullanılmış ve bir performansı belgeleme amacı taşımışlardır. Halen sanat müzelerinde ilk kavramsal işler olarak izleyicilere sunulan bu eserlerde açık bir şekilde nesneden arındırma anlayışının hâkim olduğu ve estetik değerden uzaklaşarak düşünsel süreçlerin vurgulandığ görülmektedir. Projelerde hazır haritalar kullanıldığı ve bu haritalara sanatçıların küçük müdahaleler yaparak haritaları öznel deneyimlerinin parçası haline dönüştürdükleri görülür. Böylelikle karmaşık göstergeler olarak var olan hazır haritalar başka nesnelerle de birleşerek bir projenin ya da diğer ifade ile diğer göstergelerle birlikte bir gösterge sisteminin parçasına dönüşmüştür.

1970'lerin başında, Nancy Graves de haritalar yapmaya başlamıştır. Sanatçının kavramsal çalışmalarında harita kullanımı adına en tanınan eseri 1972 yılında ürettiği "Lithographs Based on Geologic Maps of Lunar Orbiter and Apollo Landing Sites" isimli çalışmasıdır. Susan Hiller de aynı y1llarda "Composite Group Dream Map, Night of 23/24 August" gibi performas içeren rüya haritalarını üretti (Wood, 2010). 

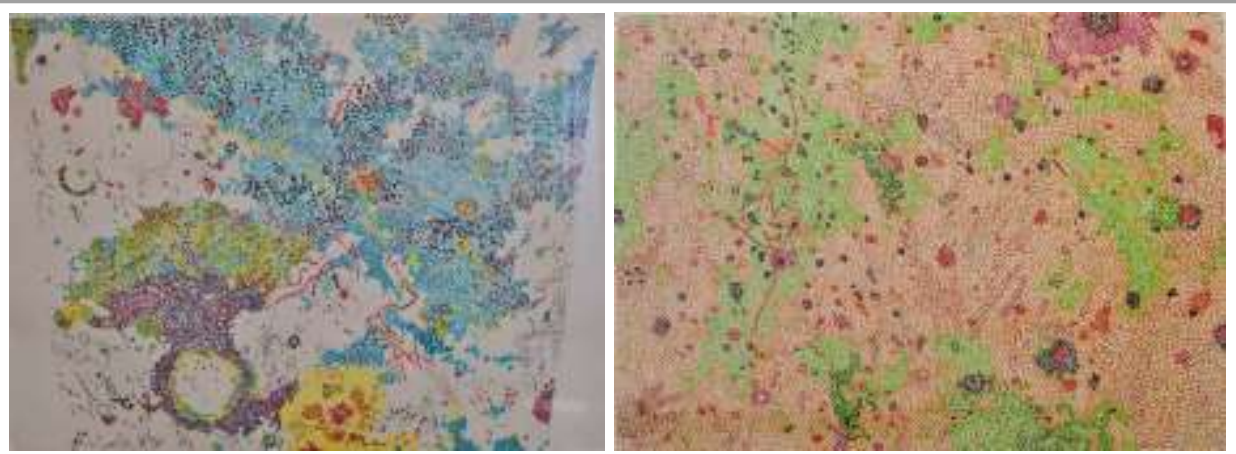

Görsel 8: Nancy Graves, 1972, "Lithographs Based on Geo- logic Maps of Lunar Orbiter and Apollo Landing Sites” "isimli seriden sol tarafta “ $V$. Mantes Apenninus Region” ve sağ tarafta “X. Riphaeus Mountains Region of the Moon" isimli çalışmalar (Public Art UHS. 2021)

Nancy Graves'in bu serisi taşbaskı tekniği ile yaptığı on adet eseri barındırmaktadır. Graves bu serisinde, eserlerle etkileșimi güçlendirmek için görsel ipuçları sağlamak adına renkleri titizlikle kullanmış ve izleyiciye eserlere bakmak için ipuçları önermiştir. Bu baskı eserler NASA'nın Apollo görevine hazırlanırken ürettiği gerçek haritaların yorumlarıdır (Public Art UHS. 2021)

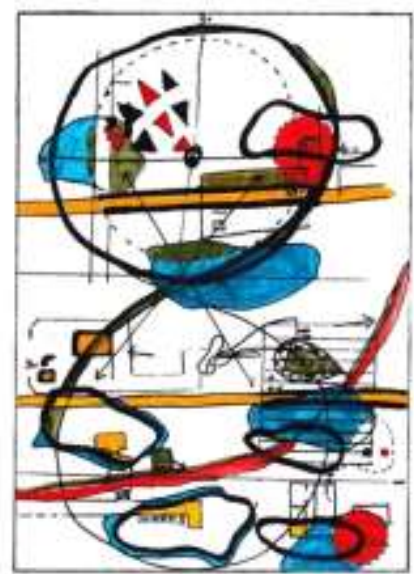
1998)

Görsel 9: Susan Hiller, "Composite Group Dream Map, Night of 23/24 August" (Hiller,

Susan Hiller primitif göstergeler ve grafik yapılarla ürettiği bu rüya haritaları ile ilgili şunları ifade etmiştir:

Spiral merdiven gibi mekânsal olarak karmaşık bir şeyi iletmek istediğimizde, onu kâğıda çizmek, onu kelimelerle tanımlamaktan daha kolaydır. Aynı şekilde, zamansal veya entelektüel olarak karmaşık olan fikirler ve deneyimler, sözlü açıklamalardan çok diyagramlardan veya haritalardan daha açık bir şekilde anlaşılabilir. Pek çok toplumda rüyalar anlatılmak yerine haritalanır veya diyagram haline getirilir. Bu 'rüya haritalarından' bazılarını kendi toplumumuzdan örneklerle ve Freud'un dinamik psişik durumların şematik temsillerinden üçünü yan yana koydum (Hiller, 1998).

Bununla birlikte, kavramsal sanat eserlerinin tamamı sanatçların kendileri tarafından yapılmamıştır. Harita kullanan diğer bir sanatçı olan Alighiero Boetti, en ünlü eseri olarak kabul gören Mappa'yı 1971 yılında ülkelerin bayraklarıyla üretilmiş işlemeli bir dünya haritası dizisi olarak sundu. Bu çalışma aslında Afgan zanaatkârlar tarafından, başlangıçta Kabil'de, daha sonra 
Peşaver'deki mülteci kamplarında yapılmıştır (Wood, 2010). Boetti kavramsal çalışmaları sürecinde nakışla da ilgilenmeye başlamıştır. Afgan zanaatkâr kadınlarla çalıştığ 1971 yılına ait bu çalışmasında üretimi gerçekleştiren kişilere bir sınırlama getirmeyen Boetti, zanaatkârların dünyayı yorumlama biçimini birleştirmiştir (İCA Map Design, 2021)

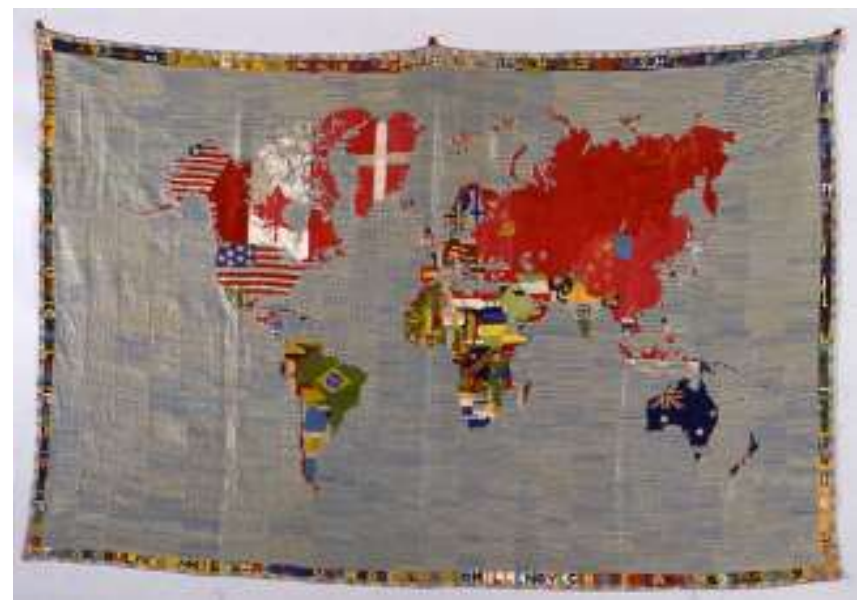

Görsel 10: Alighiero Boetti, Mappa (İCA Map Design, 2021).

Haritalar üzerine 1970'li yıllarda çalışan diğer bir kavramsal sanatçı Agnes Denes'in esrarengiz dünya haritaları yaptığı bilinmektedir. Dünyayı bir küre gibi değil, bir küp, bir halka bir piramit veya başka şekillerde temsil etmek için matematiksel olarak çarpittığ görülmektedir. Bu durum izleyiciyi harita yapım tekniğine odaklanmaya zorlamaktadır. $\mathrm{Bu}$ harita çalışmaları izleyicinin gerçeklik duygusunu yeniden değerlendirmeye zorlar ve dünyaya dair zihinsel imajımızı değiştirmeye uğraşır (Wollen, 1999: 44).

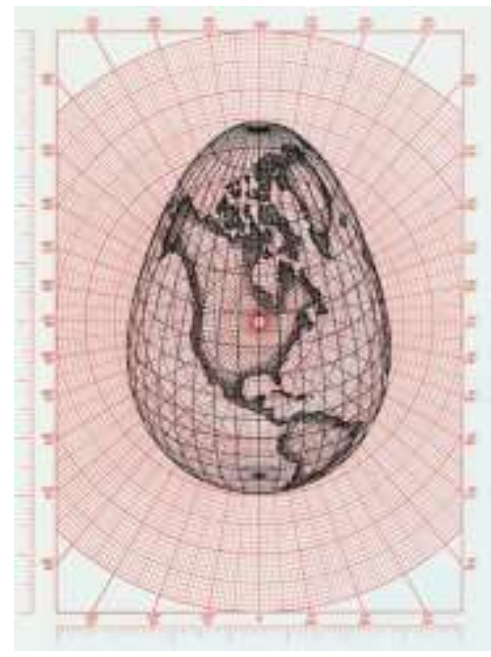

Görsel 11: Agnes Denes. Isometric Systems in Isotropic Space - Map Projections: The Egg, 1974 (Rawes, 2019: 795). 


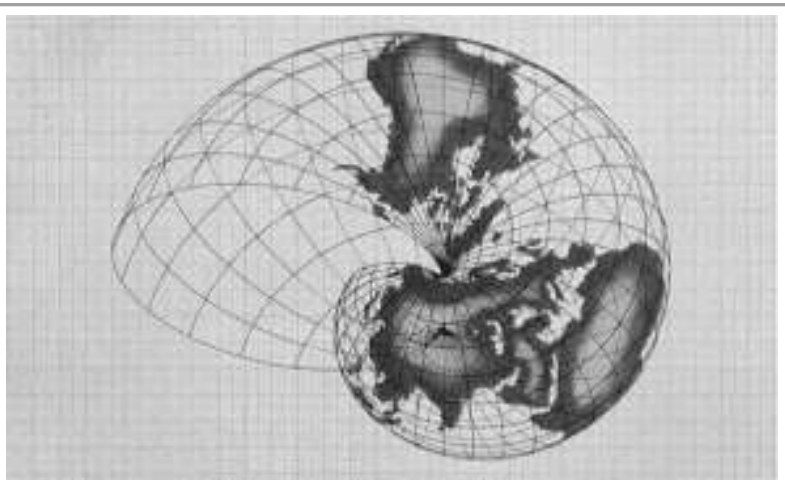

Görsel 12: Agnes Denes, Isometric Systems in Isotropic Space - Map Projections: The Snail, 1974. (Wollen, 1999:41)

Çevre sanatçısı olarak da tanınan Denes'in harita serisi, "Isometric Systems in Isotropic Space: Map Projections" 1974 ve 1976 yılları arasında dünyayı çeşitli geometrik ve organik nesneler olarak yeniden tasavvur etmiştir. Bununla birlikte, dünyanın matematiksel olarak rasyonel her çizimine organik bir ad verilir, böylece oval bir limon olur; bir elipsoid bir yumurtadır, halka bir simittir; sarmal bir toroid bir salyangozdur, silindir bir sosisli sandviçtir (Rawes, 2019: 795).

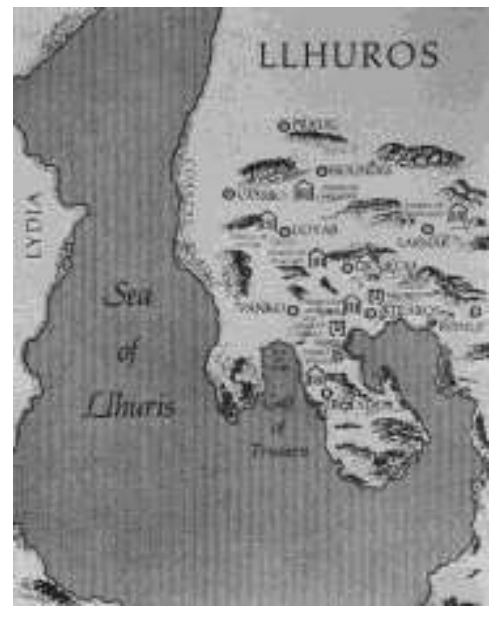

Görsel 13: Norman Daly, Llhuros, 1972. (Wollen, 1999:46)

Wollen'nın aktarımıyla; Norman Daly hayali ülkelerle ilgili haritalama yapan sanatçılardan biri olarak, haritacıların ve sanatçıların nasıl fantastik haritalama șeklinde ifade edilebilecek eserler ürettiklerini bize göstermektedir. Norman Daly'nin 1972 yılında ürettiği Llhuros haritası bu anlamda en önemli örnekler arasındadır. Wollen'a göre haritalar hem siyasi ve ideolojik araçlar hem de hayal gücü için uyarıcı olarak hizmet edebilir. Kavramsalcılar tarafından kullanılan haritalar, içinde yaşadığımız dünya hakkında bize yeni düşünme yolları ve var olan koşulları değiştirmek için yeni bakış açıları sunan ütopik bir vizyon biçimini tasvir edebilirler (Wollen, 1999:46).

1970’li y1llarda kavramsal sanatçıların ilk kavramsal sanat örneklerinden özellikle biçimsel anlamda kopuşlarının başladığı görülmektedir. Yukarıda gösterilen eserleri ile Graves, Hiller, Boetti ve Denes'in haritaları biçimsel olarak önceki örneklerden farklı bir tarzda olup geleneksel estetik değerlere daha yakın olarak yorumlanabilir. Diğer taraftan Norman Daly'nin ${ }^{5}$ Llhuros

5 1960'larda ağırlıklı olarak montajlar ve mermer oymalarla çalışarak heykelle ilgilenmeye başlayan sanatçının en kapsamlı projesi olan "Llhuros"tur. Bu çalışma bütün bir antik uygarlığın yaratılması için başlangıç noktası olarak belirlenirken kavramsal sanatın yönlerini geleneksel estetik değerlere kararlı ve dikkatli bir şekilde bu çalışmada Daly’nin birleştirdiği görülmektedir. Daly, Llhuros ile aynı zamanda arkeolojik sanat in temelini atmıştır (cornell.edu, 2021). 
isimli projesi de kavramsal bir proje olarak haritalara yer vermiştir. Bu haritaların da biçimsel olarak geleneksel estetik değerlere bağlı kaldığı ama bir yandan da kavramsal sanatın ruhunu taşıdığı belirtilmektedir.

\section{Sonuç}

Kavramsal Sanatçılar, algısal sanatları hedef alarak kavram veya düşüncenin duygudan daha önemli olduğunu vurgulamış ve çeşitli sanatsal stratejiler vasıtasıyla duygudan arındırılmış düşüncelerle izleyicileri direk buluşturmayı hedeflemişlerdir. Bu bağlamda kavramsal sanatçıların, sanatı nesnesinden arındırmak veya diğer bir ifadeyle estetik değerleri sanatlarının dışında tutmak için mücadele verdikleri görülmektedir. Özellikle ilk kavramsal çalışmalarda sanatçıların geleneksel veya modern estetik değer anlayışını dışladıkları ve formun veya nesnelerin, düşüncenin önüne geçmemesi için çaba sarf ettikleri görülmektedir. Bu süreç içerisinde pek çok sıradan nesneyi de sanatsal projelerinin içine dahil eden kavramsal sanatçıların 1960'l yıllardan başlayarak haritaları kendilerinden önceki sanatçılardan farklı bir şekilde düşünce üretimi ve belgelendirme amaçlı kullandıkları görülür.

1960'lı yılların son dönemecinde harita kullanımının kavramsal sanatta en belirgin örnekleri aynı dönemin sanatçıları olan, 'Long, Kawara ve Huebler' tarafindan verilmiştir. Bu isimlerin ürettikleri çalışmalarda sanatçıların haritaları bir proje çerçevesinde başka nesnelerle birlikte kullandıkları görülür. Genellikle performansa dayalı kavramsal işler olan bu projelerde haritalar sanatçıların gündelik hayata dair öznel fikirlerini yansıtma ve eylemleri belgeleme aracı olarak kullanılmıştır. Diğer taraftan haritalar birer karmaşık gösterge sistemidir ve harita okumasıysa genel olarak sıradan ve teknik bir okumadır. Sanatçılar projelerinde kullanmış oldukları haritaları öznel deneyimlerini belgelemek için kullanmışlardır ve artık o haritaların üzerine sanatçılar tarafından uygulanan çizgi veya yazı gibi müdahaleler izleyiciyi projedeki diğer belgelere ve süreçlere çekme görevi de görmektedir. Böylelikle gündelik hayattaki sıradan bir nesne olan haritalar sıra dışı eylemleri, olayları veya düşünceleri aktaran farklı bir bağlama yerleştirilmiştir. $\mathrm{Bu}$ çalışmaların diğer ortak noktası ise modern veya geleneksel estetik değerleri çok belirgin bir şekilde dışlamalarıdır.

1970'li yıllarla birlikte başka kavramsal sanatçıların da haritaları bir ifade aracı olarak kullanmaya devam ettikleri görülür. İlk örneklerin sonrasında 1970'li yıllarda bazı sanatçıların özellikle biçimsel olarak farklı işler çıkartmaya başladıkları ve bu anlamda üretilen işler her ne konuda olursa olsun modern veya geleneksel estetik değerleri abartılı olmamakla birlikte yansıttıkları ifade edilebilir. Böylelikle kavramsal sanatla birlikte başlayan nesneden arındırma veya estetik değerlerden uzaklaşma stratejilerinin bazı sanatçılar tarafından uygulanmadığı ancak kavramsal ve düşünsel özellikleriyle çalışmalarını ön plana çıkartma niyetlerinin bu sanatçılarda da hâkim olduğu belirtilmelidir. Haritalar bu anlamda kavramsal sanatçıların hem düşünsel hem de biçimsel anlamda yaratıcılıklarını sergileye bildikleri bir nesne olarak da belirmeye başlar. 1970'li yıllarda harita çalışmaları ağırlıklı olarak bu sebeple nesneden arındırma veya estetik değerden uzaklaşma çabası yerine yeniden bağlamsallaştırma çabasına giren işler olarak tanımlanabilir. Diğer taraftan haritaların hayal gücü ile ilişkisi, anlatım aracı olarak siyasi veya öznel meselelerin anlatımlarında da kullanılabileceğine dair bu dönemde örnekler verilmiştir. Bu yönde 1970 sonrası sanatçıların bir kısmının haritaları doğrudan kendileri ürettikleri de gözlemlenmektedir.

Sanatçının kavramsal haritasının da bulunduğu bu serisi ölümünden 11 yıl sonra 2019 yılında 16. İstanbul Bienali’nde de sanatseverlerle buluşmuştur. 


\section{Kaynakça}

Alberro, A. (2001). “At The Threshold Of Art As Informatıon". Recording Conceptual Art. Edit. Alexander Alberro, Patricia Norvell. University of California Press.

Alberro, A. (2003). Conceptual art and the politics of publicity. MIT Press.

Antmen, A. (2008). 20. Yüzyıl Batı sanatında akımlar. Sel Yayınları.

Arnason, H. H., \& Mansfield, E. C. (2012). History Of Modern Art. Pearson Education.

Bourriaud, N. (2005). İlişkisel estetik, çev. Saadet Özen. Bağlam Yayınları.

Cosgrove, D. (2005). Maps, Mapping, Modernity: Art and Cartography In The Twentieth Century. Imago Mundi, 57(1), 35-54. https://doi.org/10.1080/0308569042000289824

Cumming, R. (2008). Sanat (Görsel Rehberler), çev: Ayşe Işın Önal ve Aslı Çetinkaya. İnkılap Kitabevi.

Davies, S., Higgins, K. M., Hopkins, R., Stecker, R., \& Cooper, D. E.. (2009). A Companion To Aesthetics . John Wiley \& Sons.

Fleming, J., \& Honour, H. (2016). Dünya Sanat Tarihi, çev. Hakan Abacı. Alfa Yayınları.

Hiller, S. (1998). Dream Maps. British Journal of Psychotherapy, 14(4), 445-452.

Hopkins, D. (2000). After Modern Art 1945-2000. Oxford University Press.

Kalyva, E. (2017). Image And Text In Conceptual Art: Critical Operations İn Context. Springer.

Kolektif (1997). Eczacıbaşı Sanat Ansiklopedisi. Yem Yayınları

Lamarque, P. (2007). "On Perceiving Conceptual Art." Philosophy and Conceptual Art. Edit. Peter Goldie \& Elisabeth Schellekens. Claredon Press, 3-17.

Lippard, L., \& Chandler, J. (1968). The Dematerialization Of Art. Art International, 12(2), 31-36.

Matravers, D. (2007). "The Dematerialization Of The Object". Philosophy and Conceptual Art, Edit. Peter Goldie \& Elisabeth Schellekens. Claredon Press, 18-32.

Rawes, P. (2019). Aesthetic Geometries Of Life. Textual Practice, 33(5), 787-802. https://doi.org/10.1080/0950236X.2019.1581685

Schellekens, E. (2007). "The Aesthetic Value Of İdeas". Philosophy and Conceptual Art, Edit. Peter Goldie \& Elisabeth Schellekens. Claredon Press, 77-92.

Wood, D. (2006). Catalogue Of Map Artists. Cartographic Perspectives, (53), 61-68.

Wood, D. (2010). Rethinking The Power Of Maps. Guilford Press.

Wollen, P. (1999). "Mappings: Situationists and/or Conceptualists". Rewriting Conceptual Art, Edit. Michael Newman ve Jon Bird. London: Reaktion Book. 27-46.

\section{İnternet Kaynakları}

Art Wiki French (2020, Aralık). Douglas Huebler.

http://www.artwiki.fr/cours/technoromantisme/conceptuels.html

Brooklyn Rail, (2020, Aralık). Robert Barry Art Works

https://brooklynrail.org/2015/03/artseen/robert-barry-all-the-things-i-know-1962-to-present

Guggenheim Museum (2021, Ocak). On Kawara

https://www.guggenheim.org/audio/track/on-kawara-i-went-1968-79

www.turkishstudies.net/turkishstudies 
İCA Map Design (2021, Şubat). Aalighiero Boetti

https://mapdesign.icaci.org/2014/11/mapcarte-310365-mappa-by-alighiero-boetti-19711994/

Moma, (2021, Ocak). Joseph Kosuth

https://www.moma.org/collection/works/81435

Tate Museum (2020, Aral1k). Douglas Huebler

https://www.tate.org.uk/art/artists/douglas-huebler-1320

Tate Museum (2020, Aral1k). Long

https://www.tate.org.uk/art/artworks/long-untitled-t02065

Public Art UHS. (2021, Şubat). Nancy Graves.

http://publicartuhs.org/artwork/x-riphaeus-mountains-region-of-the-moon-from-the-seriesgeologic-maps-of-lunar-orbiter-and-apollo-landing-sites/

Yves Klein, (2021, Şubat) Blue Globe.

http://www.yvesklein.com/en/oeuvres/view/697/blue-globe/ 